\title{
Quality of life among patients undergoing decompressive craniectomy for traumatic brain injury using glasgow outcome scale extended and quality of life after brain injury scale
}

Muhammad Waqas

Aga Khan University, muhammad.waqas@aku.edu

Noor Malik

Aga Khan University, noor.malik@aku.edu

Muhammad Shahzad Shamim

Aga Khan University, shahzad.shamim@aku.edu

Karim Rizwan Nathani

Aga Khan University

Sumia Andleeb Abbasi

Aga Khan University

Follow this and additional works at: https://ecommons.aku.edu/pakistan_fhs_mc_surg_neurosurg

Part of the Neurology Commons, Neurosurgery Commons, Public Health Commons, and the Surgery Commons

\section{Recommended Citation}

Muhammad Waqas, ., Malik, N., Shamim, M., Nathani, K. R., Abbasi, S. A. (2018). Quality of life among patients undergoing decompressive craniectomy for traumatic brain injury using glasgow outcome scale extended and quality of life after brain injury scale. World Neurosurgery, 116, e783-e790.

Available at: https://ecommons.aku.edu/pakistan_fhs_mc_surg_neurosurg/162 


\section{Quality of Life Among Patients Undergoing Decompressive Craniectomy for Traumatic Brain Injury Using Glasgow Outcome Scale Extended and Quality of Life After Brain Injury Scale}

Muhammad Waqas ${ }^{1}$, Noor Malik ${ }^{1}$, Muhammad Shahzad Shamim ${ }^{1}$, Karim Rizwan Nathani ${ }^{1}$, Sumia Andleeb Abbasi ${ }^{2}$

OBJECTIVE: To assess quality of life of patients who underwent decompressive craniectomy (DC) for traumatic brain injury and satisfaction of caregivers with outcomes.

METHODS: This cross-sectional study was conducted at a tertiary care urban center in Pakistan. All patients with severe traumatic brain injury who underwent DC and survived $>6$ months were included. Outcomes were assessed using 2 scales: Glasgow Outcome Scale Extended and Quality of Life After Traumatic Brain Injury (00LIBRI). The proforma was translated and validated into the national language. Patient caregivers were interviewed to ask if they would opt for DC in a similar situation in future.

RESULTS: The study comprised 40 patients, including 35 male $(88 \%)$ and 5 female $(12 \%)$ patients. Mean age of patients was $26.5 \pm 9.5$ years. Mean Glasgow Coma Scale score at presentation was $8.34 \pm \mathbf{3 . 2 2}$. Median follow-up was 12 months (range, 6-18 months). Mean Glasgow Outcome Scale Extended score was $5.35 \pm 1.9$, which correlates with an unfavorable outcome. Mean 0OLIBRI score was $59.65 \pm 21.27$. Family members of $38(95 \%)$ patients were content with their decision to give consent for DC in their patients. Spearman correlation for different domains of QOLIBRI and Glasgow Outcome Scale Extended was statistically significant for all parameters except social relationship.

CONCLUSIONS: Mean QOLIBRI score of patients undergoing DC was $59.65 \pm 21.27$. Most caregivers (95\%) were satisfied with their decision to consent for DC. Patient-reported health-related quality of life assessment is necessary to assess impact of traumatic brain injury.

\section{INTRODUCTION}

$\mathrm{D}$ ecompressive craniectomy (DC) is performed to lower intracranial pressure in various clinical conditions, such as stroke and severe traumatic brain injury (TBI), and is regarded as the last tier in the management of raised intracranial pressure. $^{\mathrm{I}, 2}$ There is plenty of literature on the outcomes of DC, and most studies have focused on the survival and functional outcomes of these patients. Tools to assess functional outcomes of patients with TBI, such as the Glasgow Outcome Scale (GOS), were developed in the 1970s. ${ }^{2}$ Functional outcome scales, although extremely useful, remain basic and do not reflect patients' quality of life (QOL) or level of satisfaction with their health status. Clinical trials on DC for patients with severe TBI have also used survival and functional outcomes as study endpoints, and disease-specific health-related quality of life (HRQOL) has been largely overlooked as a vital endpoint with the exception of a few studies. ${ }^{3-6}$ In fact, very little is known about HRQOL for patients after DC even though for patients with long-term survival after DC and their caregivers, QOL becomes as important as functional status. As such, the true impact of TBI on patients' lives cannot be estimated without studying HRQOL. The objective of this study was to assess QOL of patients who underwent DC for TBI. The second objective of the study was to assess

\section{Key words}

- Decompressive craniectomy

- 0OLIBRI

- Quality of life

- Severe traumatic brain injury

\section{Abbreviations and Acronyms}

DC: Decompressive craniectomy

GoS: Glasgow Outcome Scale

GOSE: Glasgow Outcome Scale Extended

HROOL: Health-related quality of life

Q0L: Quality of life

0.0LIBRI: Quality of Life After Brain Injury
SF-36: 36-Item Short Form Health Survey

TBI: Traumatic brain injury

From the ${ }^{\mathbf{1}}$ Section of Neurosurgery, Aga Khan University Hospital Karachi; and ${ }^{\mathbf{2} D e p a r t m e n t}$ of Community Health Sciences, The Aga Khan University Karachi, Karachi, Pakistan

To whom correspondence should be addressed: Muhammad Shahzad Shamim, M.D.

[E-mail: shahzad.shamim@aku.edu]

Citation: World Neurosurg. (2018) 116:e783-e790.

https://doi.org/10.1016/j.wneu.2018.05.092

Journal homepage: www.WORLDNEUROSURGERY.org

Available online: www.sciencedirect.com

1878-8750/\$ - see front matter (c) 2018 Elsevier Inc. All rights reserved. 
the satisfaction of the caregivers with the outcomes of the procedure. They were asked if they would opt for DC if faced with a similar situation in the future.

\section{MATERIALS AND METHODS}

This cross-sectional study was conducted at a tertiary care urban center in Pakistan from January 2013 to June 2015. Approval was obtained from the Ethical Review Committee. All patients with TBI who underwent DC with a GCS score of $\leq 8$ were included in the study. Patients who died within 6 months of surgery, patients whose families did not give consent for the study, and patients with incomplete records were excluded from the study. Data were collected on a self-designed pro forma using hospital electronic medical records for patient-related information and laboratory and radiology reports. QOL assessments were done using 2 scoring systems, the Glasgow Outcome Scale Extended (GOSE) and Quality of Life After Traumatic Brain Injury (QOLIBRI). GOSE is an internationally accepted scale for functional outcome and has different domains to test consciousness; independence at home; independence outside home; work, social, and leisure activities; family and friendship; and return to normal life. Scores were calculated on the basis of these domains. Any score $<5$ represented an unfavorable outcome, and a score $>7$ represented a favorable outcome. a score of 8 was taken as the best score. On the basis of this score, the patient's functional status was categorized into 8 separate categories. ${ }^{4}$ QOLIBRI is also a recognized scoring system that is a disease-specific measure of HRQOL after TBI. Using this proforma, we assessed cognition, self-satisfaction and level of energy, daily life and autonomy, social relationships, emotions, and physical problems. A scale of o-Ioo was calculated, where o was the worst possible QOL and roo was the best possible QOL. The QOLIBRI proforma was translated into Urdu (national language) and was tested and validated by our team of statisticians before application. The scale is shown in the Appendix.

Data were analyzed using IBM SPSS Version 23 (IBM Corp., Armonk, New York, USA). Continuous variables with normal and skewed distributions were represented as mean $\pm \mathrm{SD}$ and median (interquartile range), respectively. Categorical data were represented as percentage and proportions. Means were compared with the help of independent sample $t$ test, whereas $\chi^{2}$ test was used to compare the categorical data. Spearman correlation was used see the mutual correlation of GOSE and QOLIBIRI scales.

\section{RESULTS}

During the study period, 88 patients underwent DC after TBI. Of these 88 patients, 36 had died within 6 months of the procedure, and 12 patients were excluded because of missing data. Thus, the final sample size was 40 . The study included 35 male (88\%) and 5 female (I $\%$ ) patients. The mean age of the study population was $26.5 \pm 9.5$ years (interquartile range of $20-32$ years). Mean GCS score at presentation was $8.34 \pm 3.22$. Demographics and clinical characteristics of the patients are presented in Table 1.

There were 34 patients eligible for QOLIBRI assessment, whereas 40 patients were assessed using GOSE. The reason for fewer patients in the QOLIBRI group was a lack of response on more than one third questions by 6 patients. Median follow-up
Table 1. Demographics and Clinical Characteristics of the

Study Population

\begin{tabular}{lc} 
Variable & Value \\
\hline Male sex & $35(88 \%)$ \\
\hline Age, years & $26.5 \pm 9.5$ \\
\hline Married & $26(65 \%)$ \\
\hline Rotterdam score & $3.5 \pm 0.8$ \\
\hline Subdural hematoma & $26(65 \%)$ \\
\hline GCS score at presentation & $8.3 \pm 3.2$ \\
\hline Unilateral DC & $34(85 \%)$ \\
\hline Postoperative GCS score & $12.4 \pm 2.8$ \\
\hline LOS, days & $12 \pm 6$ \\
\hline Cranioplasty & $36(90 \%)$ \\
\hline Follow-up, months, median (range) & $12(6-18)$
\end{tabular}

Values are reported as number (\%) or mean \pm SD except as noted.

DC, decompressive craniectomy; GCS, Glasgow Coma Scale; LOS, length of stay.

was I2 months (range, 6-I8 months). Of 40 patients, 34 underwent unilateral DC, whereas 6 patients underwent bilateral DC. Subdural hemorrhage and contusions were the most common injuries for which DC was undertaken $(65 \%)$. After decompression, 36 patients ( $90 \%$ ) underwent cranioplasty; 4 patients did not undergo cranioplasty.

The mean GOSE score was $5.35 \pm$ I.9, which correlates with an unfavorable outcome. The mean QOLIBRI score was $59.65 \pm$ 21.27. However, family members of $38(95 \%)$ patients were content with their decision to consent for DC in their patients.

Table 2 shows functional outcomes and QOL of patients after DC, and Table 3 shows the distribution of patients in various categories of QOLIBRI. Different domains of QOLIBRI and GOSE scales were tested on Spearman correlation test, and they correlated with each other, as the $P$ value was statistically significant for all parameters except social relationship (Table 4). The correlation between mean QOLIBRI and GOSE is shown in Figure 1.

\section{DISCUSSION}

Most outcome data on DC come from developed countries with government-funded health care and availability of rehabilitation centers. We have previously reported our experience and outcomes of DC for TBI. ${ }^{3,4}$ Most of TBI patients with TBI are young, and only a small minority of these patients have health insurance. ${ }^{3-5}$ In the absence of government-funded health care and rehabilitation centers, the financial and psychological burden on the families of patients with TBI is perhaps incalculable. ${ }^{6}$ Physicians involved in TBI management in underdeveloped countries such as ours often face the immensely difficult situation where families request discontinuation of treatment owing to financial limitations. At the other extreme are situations where initially the families push physicians for lifesaving treatment, but later 
Table 2. Functional Outcomes and Quality of Life of Patients After Decompressive Craniectomy

\begin{tabular}{|lc|}
\hline Scale/Domain & Value \\
\hline GOSE & $5.3 \pm 2$ \\
\hline OOLIBRI & $59.65 \pm 21.27$ \\
\hline Cognition & $3.4 \pm 1.0$ \\
\hline Self-satisfaction and level of energy & $3.3 \pm 1.3$ \\
\hline Daily life and autonomy & $3.3 \pm 1.1$ \\
\hline Social relationships & $3.6 \pm 1.1$ \\
\hline Emotions & $3.1 \pm 1.2$ \\
\hline Physical problems & $3.4 \pm 1.1$ \\
\hline Lower severe disability & $12(30 \%)$ \\
\hline Upper severe disability & $4(10 \%)$ \\
\hline Lower moderate disability & $3(7.5 \%)$ \\
\hline Upper moderate disability & $5(12.5 \%)$ \\
\hline Lower good recovery & $11(27.5 \%)$ \\
\hline Upper good recovery & $5(12.5 \%)$ \\
\hline $\begin{array}{l}\text { Values are reported as mean } \pm \text { SD and number (\%). } \\
\text { GOSE, Glasgow Outcome Scale Extended; Q0LBRI, Quality of Life After Brain Injury. }\end{array}$ \\
\hline
\end{tabular}

on when the patient does not show improvement and the financial burdens continue to increase, families begin to regret their initial decisions. In these situations, knowledge of long-term QOL can assist both physicians and families to make a more informed decision for the patient for or against continuation of care.

Although DC for TBI has been shown to improve survival, improvement in functional outcomes and QOL has been debated..$^{7-10}$ Patients' survival cannot be the only outcome without taking into account functional status and QOL. ${ }^{8, \mathrm{II}, \mathrm{I2}} \mathrm{QOL}$ after DC has hardly been studied in the literature. Danish et al., ${ }^{13}$ in a

Table 3. Distribution of Patients in Various Categories of Quality of Life After Brain Injury

\begin{tabular}{|lc|}
\hline Scale & Number (\%) \\
\hline $1-10$ & 0 \\
\hline $11-20$ & $1(2.9)$ \\
\hline $21-30$ & $2(5.8)$ \\
\hline $31-40$ & $4(11.7)$ \\
\hline $41-50$ & $6(17.6)$ \\
\hline $51-60$ & $5(14.7)$ \\
\hline $61-70$ & $5(14.7)$ \\
\hline $71-80$ & $4(11.7)$ \\
\hline $81-90$ & $5(14.7)$ \\
\hline $91-100$ & $2(5.8)$ \\
\hline
\end{tabular}

Table 4. Correlation of Different Domains of Quality of Life After Brain Injury with Glasgow Outcome Scale Extended

\begin{tabular}{|lcc|}
\hline Domains of O0LIBRI & $\begin{array}{c}\text { Pearson } \\
\text { Correlation } \boldsymbol{r}\end{array}$ & P \\
\hline OaN (cognition) & 0.46 & 0.008 \\
\hline ObN (self-satisfaction and level of energy) & 0.56 & $<0.001$ \\
\hline OcN (daily life and autonomy) & 0.7 & $<0.001$ \\
\hline OdN (social relationship) & 0.24 & 0.176 \\
\hline OeN (emotions) & 0.33 & 0.04 \\
\hline OfN (physical problems) & 0.41 & 0.017 \\
\hline OOLBRI, Quality of Life After Brain Injury. & & \\
\hline
\end{tabular}

systematic review on this topic, equated QOL with GOS score and summarized the evidence from various studies on DC that had measured GOS. The mean QOL (derived from GOS score) in survivors at 6 months was $0.59 \cdot{ }^{13}$ This roughly corresponded to a GOS score of 4 indicating favorable outcomes. This systematic review published in 2009 did not include a single study using HRQOL scales. HRQOL has also been overlooked by major trials on DC, such as RESCUE-ICP (Randomised Evaluation of Surgery with Craniectomy for Uncontrollable Elevation of Intracranial Pressure) and DECRA (Decompressive Craniectomy). ${ }^{\mathrm{I}, \mathrm{I} 5}$ Although RESCUE-ICP mentioned the use of the 36-Item Short Form Health Survey (SF-36) in the protocol, the QOL-related outcomes have not yet been published to our knowledge. $^{15}$

QOLIBRI is a head injury-specific QOL assessment tool and is scored $\mathrm{o}-\mathrm{Io0}$, where o indicates worst possible QOL, and Ioo represents best possible QOL. ${ }^{\text {(6-18 }}$ A systematic review by Polinder et al. $^{\text {I9 }}$ highlighted the need to use a standardized scale for uniformity and comparability of different studies. According to the meta-analysis, QOLIBRI showed excellent content, structural validity, and internal consistency, whereas the internal

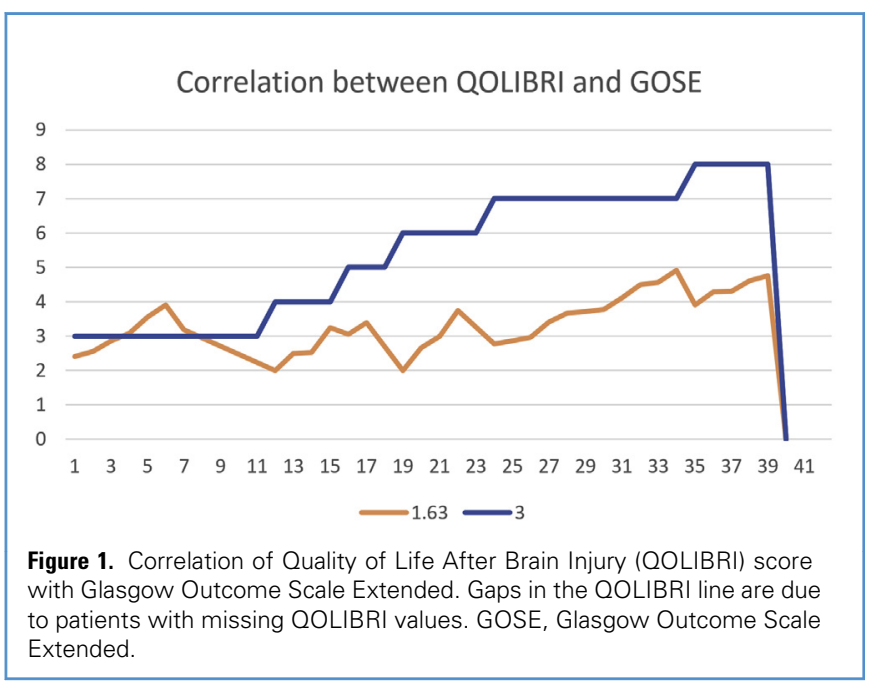


consistency of SF-36 ranged from good to fair. ${ }^{19}$ Most studies that looked at HRQOL used SF-36, which is not a disease-specific scale. $^{20}$ von Steinbuechel et al. ${ }^{20}$ compared QOLIBRI with the more generic SF-36 scale. QOLIBRI subscales showed a better discriminatory power than the specific SF-36 scales role physical, role emotional, and social functioning. The authors recommended QOLIBRI to differentiate individuals in a specific dimension and/or health state. ${ }^{20}$ We found that QOLIBRI and GOSE correlate with each other for all domains except social relationship. The mutual correlation is described in Table 4 and Figure 1. The Pearson correlation value of $0.6 \mathrm{I}$ indicates a moderately strong correlation; however, GOSE cannot replace the HRQOL scales because it assesses functional status only and is not patient reported. Of all the domains of QOLIBRI, correlation with best with the GOSE domain of autonomy $(r=$ $0.7 \mathrm{I})$. This supports the fact that autonomy and functional ability are related.

We preferred to use the disease-specific HRQOL scale in contrast to the more generic SF-36. The mean QOLIBRI score of our patient population was $59.65 \pm 2 \mathrm{I} .27$, and $61.6 \%$ of patients scored $>50$. The results of our study are not very different from previous studies. Soberg et al. ${ }^{21}$ published their results of 126 patients with a mean QOLIBRI score of $68 \pm$ i8. A metaanalysis identified only 9 studies that looked at HRQOL in patients with TBI. ${ }^{22}$ However, no studies specifically looked at patients who had undergone DC. Our study adds to the existing data on HRQOL in patients with TBI and is the first to report
HRQOL in developing countries, where there is hardly any support for patients with TBI and their families.

Although the QOL literature on DC for TBI is sparse, QOL has been extensively studied in patients undergoing DC for middle cerebral artery infarcts. ${ }^{23-25}$ In a study on QOL, $77 \%$ of patients were satisfied with their QOL and would give consent for the procedure again. ${ }^{24} \mathrm{We}$ asked a similar question to the family members, and $38(95 \%)$ were satisfied with the outcomes of the procedure and would consent for it again.

Limitations of this study include the relatively small sample size and the fact that the patients and/or their caregivers were interviewed by telephone rather than in person. We interviewed only families regarding the decision on DC, as they are the ones involved in decision making at the time of surgery. However, it would have been interesting to know the perspective of patients themselves. Prospective studies with larger sample size and direct interview may validate these findings. We believe that the study provides much needed insight into HRQOL of patients undergoing DC in the setting of a developing country trauma center.

\section{CONCLUSIONS}

DC is associated with a moderate QOL with a mean score of 59.65 \pm 2 I.27 on the QOLIBRI scale. Most caregivers (95\%) were satisfied with their decision to consent for DC. Prospective patient-reported HRQOL assessment is necessary to measure the impact of TBI on QOL of patients.

\section{REFERENCES}

I. Chesnut RM, Marshall LF, Klauber MR, Blunt BA, Baldwin N, Eisenberg HM, et al. The role of secondary brain injury in determining outcome from severe head injury. J Trauma. I993;34:216-222.

2. Jennett B, Bond M. Assessment of outcome after severe brain damage: a practical scale. Lancet. I975;305:480-484

3. Wagas M, Shamim MS, Enam SF, Qadeer M, Bakhshi SK, Patoli I, et al. Predicting outcomes of decompressive craniectomy: use of rotterdam computed tomography classification and marshall classification. Br J Neurosurg. 20I6;30:258-263.

4. Shamim M, Qadeer M, Murtaza G, Enam SA, Farooqi NB. Emergency department predictors of tracheostomy in patients with isolated traumatic brain injury requiring emergency cranial decompression. J Neurosurg. 20II;II5:I007-IOI2.

5. Waqas M, Bakhshi S, Shamim M, Anwar S. Radiological prognostication in patients with head trauma requiring decompressive craniectomy: analysis of optic nerve sheath diameter and Rotterdam CT. Scoring J Neuroradiol. 2016;43:25-30.

6. Hyder AA, Rotllant G, Morrow RH. Measuring the burden of disease: healthy life-years. Am J Public Health. I998;88:196-202.

7. Sahuquillo J, Martínez-Ricarte F, Poca MA. Decompressive craniectomy in traumatic brain injury after the DECRA trial. Where do we stand? Curr Opin Crit Care. 2013;I9:IOI-Io6.
8. Lönnqvist PA. Medical research and the ethics of medical treatments: disability-free survival. $\mathrm{Br} \mathrm{J}$ Anaesth. 2017;118:286-288.

9. Ferri CP, Buehler A, Flato UAP, Puglia Junior P, Fernandes JG. Endovascular thrombectomy for the treatment of acute ischemic stroke. Arq Neuropsiquiatr. 2016;74:67-74

Io. Menon DK, Kolias AG, Servadei F, Hutchinson PJ. Survival with disability. Whose life is it, anyway? Br J Anaesth. 20I7;IIg:I062-I063.

II. Walcott BP, Kahle KT, Simard JM. The DECRA trial and decompressive craniectomy in diffuse traumatic brain injury: is decompression really ineffective? World Neurosurg. 2013;79:80-8I.

I2. Cooper DJ, Rosenfeld JV, Wolfe R. DECRA Investigators' Response to "The future of decompressive craniectomy for diffuse traumatic brain injury" by Honeybul et al. J Neurotrauma. 2012;29: $2595-2596$.

I3. Danish SF, Barone D, Lega BC, Stein SC. Quality of life after hemicraniectomy for traumatic brain injury in adults. Neurosurg Focus. 2009;26:E2.

I4. Cooper DJ, Rosenfeld JV, Murray L, Arabi YM, Davies AR, D'Urso P, et al. Decompressive craniectomy in diffuse traumatic brain injury. $N$ Engl J Med. 20II;364:I493-I502.

I5. Hutchinson PJ, Corteen E, Czosnyka M, Mendelow AD, Menon DK, Mitchell P, et al. Decompressive craniectomy in traumatic brain injury: the randomized multicenter RESCUEicp study (www.RESCUEicp.com). Acta Neurochir Suppl. 2006;96:17-20.

I6. von Steinbüchel N, Wilson L, Gibbons $\mathrm{H}$, Hawthorne G, Höfer S, Schmidt S, et al. Quality of Life after Brain Injury (QOLIBRI): scale validity and correlates of quality of life. J Neurotrauma. 20I0;27:II57-II65.

I7. Truelle JL, Koskinen S, Hawthorne G, Sarajuuri J, Formisano R, Von Wild K, et al. Quality of life after traumatic brain injury: the clinical use of the QOLIBRI, a novel disease-specific instrument. Brain Inj. 20I0;24:I272-I29I.

I8. von Steinbuechel N, Petersen C, Bullinger M. QOLIBRI Group. Assessment of health-related quality of life in persons after traumatic brain injury-development of the QOLIBRI, a specific measure. Acta Neurochir Suppl. 2005;93:43-49.

I9. Polinder S, Haagsma JA, van Klaveren D, Steyerberg EW, van Beeck EF. Health-related quality of life after TBI: a systematic review of study design, instruments, measurement properties, and outcome. Popul Health Metr. 2015;13:4.

20. von Steinbuechel N, Covic A, Polinder S, Kohlmann T, Cepulyte U, Poinstingl H, et al. Assessment of health-related quality of life after TBI: comparison of a disease-specific (QOLIBRI) with a generic (SF-36) instrument. Behav Neurol. 2016;2016:79280I4.

2I. Soberg H, Røe C, Anke A, Arango-Lasprilla JC, Skandsen T, Sveen U, et al. Health-related quality of life 12 months after severe traumatic brain 
injury: a prospective nationwide cohort study. J Rehabil Med. 2013;45:785-79I.

22. Di Battista A, Soo C, Catroppa C, Anderson V. Quality of life in children and adolescents post-

TBI: a systematic review and meta-analysis.

J Neurotrauma. 2012;29:1717-I727.

23. Skoglund TS, Eriksson-Ritzén C, Sörbo A, Jensen C, Rydenhag B. Health status and life satisfaction after decompressive craniectomy for malignant middle cerebral artery infarction. Acta Neurol Scand. 2008;117:305-310.

24. Rahme R, Zuccarello M, Kleindorfer D, Adeoye OM, Ringer AJ. Decompressive hemicraniectomy for malignant middle cerebral artery territory infarction: is life worth living? J Neurosurg. 2012;117:749-754.

25. Woertgen C, Erban P, Rothoerl RD, Bein T, Horn M, Brawanski A. Quality of life after decompressive craniectomy in patients suffering from supratentorial brain ischemia. Acta Neurochir (Wien). 2004;146:69I-695.

Conflict of interest statement: The authors declare that the article content was composed in the absence of any commercial or financial relationships that could be construed as a potential conflict of interest.

Received 18 March 2018; accepted 14 May 2018

Citation: World Neurosurg. (2018) 116:e783-e790.

https://doi.org/10.1016/j.wneu.2018.05.092

Journal homepage: www.WORLDNEUROSURGERY.org

Available online: www.sciencedirect.com

1878-8750/\$ - see front matter (C) 2018 Elsevier Inc. All rights reserved. 


\section{APPENDIX}

\section{QOLIBRI-QuaLITY of LifE AfTER BRAIN INJURY}

In the first part of this questionnaire, we would like to know how satisfied you are with different aspects of your life since your brain injury. For each question, please choose the answer that is closest to how you feel now (including the past week) and mark the box with an "X." If you have problems filling out the questionnaire, please ask for help.

Part 1

A. These questions are about your thinking abilities now (including the past week).

\begin{tabular}{|l|l|l|l|}
\hline & \multicolumn{1}{|c|}{ Not } \\
at all & Slightly & Moderately Quite Very \\
\hline $\begin{array}{l}\text { 1. How satisfied are you } \\
\text { with your ability to } \\
\text { concentrate, for example, } \\
\text { when reading or keeping } \\
\text { track of a conversation? }\end{array}$ \\
\hline $\begin{array}{l}\text { 2. How satisfied are you } \\
\text { with your ability to express } \\
\text { yourself and understand } \\
\text { others in a conversation? }\end{array}$ \\
\hline $\begin{array}{l}\text { 3. How satisfied are you } \\
\text { with your ability to } \\
\text { remember everyday things, } \\
\text { for example, where you } \\
\text { have put things? }\end{array}$ \\
\hline $\begin{array}{l}\text { 4. How satisfied are you } \\
\text { with your ability to plan and } \\
\text { work out solutions to } \\
\text { everyday practical problems, } \\
\text { for example, what to do } \\
\text { when you lose your keys? }\end{array}$ \\
\hline $\begin{array}{l}\text { 5. How satisfied are you } \\
\text { with your ability to make } \\
\text { decisions? }\end{array}$ \\
\hline $\begin{array}{l}\text { 6. How satisfied are you } \\
\text { with your ability to find your } \\
\text { way around? }\end{array}$ \\
\hline $\begin{array}{l}\text { 7. How satisfied are you } \\
\text { with your speed of thinking? }\end{array}$ \\
\hline
\end{tabular}

B. These questions are about your emotions and view of yourself now (including the past week).

\begin{tabular}{|l|l|}
\hline \multicolumn{1}{|c|}{$\begin{array}{l}\text { Not } \\
\text { at all Slightly }\end{array}$} & Moderately Quite Very \\
\hline $\begin{array}{l}\text { 1. How satisfied are you } \\
\text { with your level of energy? }\end{array}$ \\
\hline $\begin{array}{l}\text { 2. How satisfied are you } \\
\text { with your level of motivation } \\
\text { to do things? }\end{array}$ \\
\hline $\begin{array}{l}\text { 3. How satisfied are you } \\
\text { with your self-esteem, how } \\
\text { valuable you feel? }\end{array}$ \\
\hline $\begin{array}{l}\text { 4. How satisfied are you } \\
\text { with the way you look? }\end{array}$ \\
\hline $\begin{array}{l}\text { 5. How satisfied are you } \\
\text { with what you have } \\
\text { achieved since your brain } \\
\text { injury? }\end{array}$ \\
\hline $\begin{array}{l}\text { 6. How satisfied are you } \\
\text { with the way you perceive } \\
\text { yourself? }\end{array}$ \\
\hline 7. How satisfied are you \\
with the way you see your \\
future?
\end{tabular}


C. These questions are about your independence and how you function in daily life now (including the past week).

\begin{tabular}{|l|l|}
\hline \multicolumn{1}{|c|}{$\begin{array}{l}\text { Not } \\
\text { at all Slightly }\end{array}$ Moderately Quite Very } \\
\hline $\begin{array}{l}\text { 1. How satisfied are you with } \\
\text { the extent of your } \\
\text { independence from others? }\end{array}$ \\
\hline $\begin{array}{l}\text { 2. How satisfied are you with } \\
\text { your ability to get out and } \\
\text { about? }\end{array}$ \\
\hline $\begin{array}{l}\text { 3. How satisfied are you with } \\
\text { your ability to carry out } \\
\text { domestic activities, for } \\
\text { example, cooking or repairing } \\
\text { things? }\end{array}$ \\
\hline $\begin{array}{l}\text { 4. How satisfied are you with } \\
\text { your ability to run your } \\
\text { personal finances? }\end{array}$ \\
\hline $\begin{array}{l}\text { 5. How satisfied are you with } \\
\text { your participation in work or } \\
\text { education? }\end{array}$ \\
\hline $\begin{array}{l}\text { 6. How satisfied are you with } \\
\text { your participation in social and } \\
\text { leisure activities, for example, } \\
\text { sports, hobbies, parties? }\end{array}$ \\
\hline $\begin{array}{l}\text { 7. How satisfied are you with } \\
\text { the extent to which you are in } \\
\text { charge of your own life? }\end{array}$ \\
\hline
\end{tabular}

D. These questions are about your social relationships now (including the past week).

\begin{tabular}{|c|c|c|c|c|c|}
\hline & $\begin{array}{l}\text { Not } \\
\text { at all }\end{array}$ & Slightly & Moderately & Quite & Very \\
\hline $\begin{array}{l}\text { 1. How satisfied are you } \\
\text { with your ability to feel } \\
\text { affection toward others, for } \\
\text { example, your partner, } \\
\text { family, friends? }\end{array}$ & & & & & \\
\hline $\begin{array}{l}\text { 2. How satisfied are you } \\
\text { with your relationships with } \\
\text { members of your family? }\end{array}$ & & & & & \\
\hline $\begin{array}{l}\text { 3. How satisfied are you } \\
\text { with your relationships with } \\
\text { your friends? }\end{array}$ & & & & & \\
\hline $\begin{array}{l}\text { 4. How satisfied are you } \\
\text { with your relationship with a } \\
\text { partner or with not having a } \\
\text { partner? }\end{array}$ & & & & & \\
\hline $\begin{array}{l}\text { 5. How satisfied are you } \\
\text { with your sex life? }\end{array}$ & & & & & \\
\hline $\begin{array}{l}\text { 6. How satisfied are you } \\
\text { with the attitudes of other } \\
\text { people toward you? }\end{array}$ & & & & & \\
\hline
\end{tabular}

Part 2

In the second part, we would like to know how bothered you feel by different problems. For each question, please choose the answer that is closest to how you feel now (including the past week) and mark the box with an "X." If you have problems filling out the questionnaire, please ask for help.

E. These questions are about how bothered you are by your feelings now (including the past week).

\begin{tabular}{|l|l|}
\hline \multicolumn{1}{|c|}{$\begin{array}{l}\text { Not } \\
\text { at all Slightly Moderately Quite Very }\end{array}$} \\
\hline $\begin{array}{l}\text { 1. How bothered are you by } \\
\text { feeling lonely, even when } \\
\text { you are with other people? }\end{array}$ \\
\hline $\begin{array}{l}\text { 2. How bothered are you by } \\
\text { feeling bored? }\end{array}$ \\
\hline $\begin{array}{l}\text { 3. How bothered are you by } \\
\text { feeling anxious? }\end{array}$ \\
\hline $\begin{array}{l}\text { 4. How bothered are you by } \\
\text { feeling sad or depressed? }\end{array}$ \\
\hline $\begin{array}{l}\text { 5. How bothered are you by } \\
\text { feeling angry or aggressive? }\end{array}$ \\
\hline
\end{tabular}


F. These questions are about how bothered you are by physical problems now (including the past week).

\begin{tabular}{|c|c|c|c|c|c|}
\hline & $\begin{array}{l}\text { Not } \\
\text { at all }\end{array}$ & Slightly & Moderately & Quite & Very \\
\hline $\begin{array}{l}\text { 1. How bothered are you by } \\
\text { slowness and/or clumsiness } \\
\text { of movement? }\end{array}$ & & & & & \\
\hline $\begin{array}{l}\text { 2. How bothered are you by } \\
\text { effects of any other injuries } \\
\text { you sustained at the same } \\
\text { time as your brain injury? }\end{array}$ & & & & & \\
\hline $\begin{array}{l}\text { 3. How bothered are you by } \\
\text { pain, including headaches? }\end{array}$ & & & & & \\
\hline $\begin{array}{l}\text { 4. How bothered are you by } \\
\text { problems with seeing or } \\
\text { hearing? }\end{array}$ & & & & & \\
\hline $\begin{array}{l}\text { 5. Overall, how bothered are } \\
\text { you by the effects of your } \\
\text { brain injury? }\end{array}$ & & & & & \\
\hline
\end{tabular}

Adapted from qolibri.net. 